Tadeja ZUPANČIČ

Tomaž NOVLJAN

Matevž JUVANČIČ

Špela VEROVŠEK

Maruška ŠUBIC KOVAČ

Andreja ISTENIČ STARČIČ

Matija SVETINA

\title{
Konkretizacija pojma trajnostnega prostorskega razvoja za oceno osveščenosti otrok in mladostnikov
}

Prispevek je usmerjen k celovitemu sooblikovanju pogojev za tvorno izobraževanje o učinkovitih, konkretnih prispevkih k trajnostni razvojni usmeritvi, s poudarkom na grajenem okolju oziroma arhitekturi. Opredeljuje vlogo izobraževanja o grajenem okolju oziroma arhitekturi v konceptu trajnostnega razvoja; določa izhodišča za prilagajanje načinov posredovanja arhitekturnih vsebin ter opredeljuje izobraževalne vsebine in njihove predstavitve glede na razvojne sposobnosti ciljne publike. Predstavlja torej razmislek o opredmetenju pojma trajnostni prostorski razvoj za oceno osveščenosti otrok in mladostnikov $0 \gg$ trajnostnih arhitekturnih « temah ter tudi za ugotavljanje usposobljenost vzgojiteljev in učiteljev za posredovanje znanja s področja grajenega okolja v povezavi $s$ trajnostnim razvojem. Konkretiza- cija pomeni izbor in vizualizacijo aktualnih konkretnih pojavov $\mathrm{v}$ prostoru za izbrano ciljno publiko - $\mathrm{v}$ prispevku so prikazani vzorčni primeri. Prispeva $k$ razvoju »kulturne « dimenzije trajnosti prostorskega razvoja. Prizadevanja vodijo $\mathrm{k}$ razvoju sistema vseživljenjskega učenja o arhitekturi ter njenem vplivu na naš vsakdan in naš jutri.

Ključne besede: kulturna trajnost razvoja, arhitektura, grajeno okolje, vseživljenjsko učenje, otroci in mladostniki 


\section{Uvod}

Članek predstavlja rezultate prvega mejnika raziskovalne naloge, z naslovom Izobraževanje o grajenem okolju za trajnostni razvoj Slovenije, ki se izvaja v okviru nacionalnega Ciljnega raziskovalnega programa Konkurenčnost Slovenije 2006-2013. Gre za vidno konkretizacijo pojma kulturne trajnosti prostorskega razvoja za posebno ciljno publiko.

Med pisanjem članka je bil pripravljen izbor aktualnih konkretnih pojavov $\mathrm{v}$ prostoru $\mathrm{z}$ vidika kulturne trajnostni prostorskega razvoja, ki ga dopolnjuje anketni vprašalnik za učence in dijake. Komentirali naj bi ga tudi njihovi učitelji. $V$ drugem delu raziskave sledi konkreten eksperimentalni del, ki bo opravljen na vzorčnih osnovnih šolah in gimnazijah v Sloveniji (med pripravami članka $v$ izvajanju), ter ocena osveščenosti otrok in mladostnikov (pa tudi njihovih učiteljev) z vidika razumevanja pojma kulturne trajnosti prostorskega razvoja.

Temeljno izhodišče celotnega projekta je podpora vladi in drugim pomembnim akterjem Slovenije pri oblikovanju in izvajanju politik za doseganje medgeneracijskega in sonaravnega razvoja, ki uveljavlja načela trajnosti na vsa področja razvoja. Sinergija težišč »vzpostavljanja in razvijanja kulturne identitete « ter »povezovanje ukrepov za doseganje trajnostnega razvoja « oblikujeta družbo znanja, ki » trajnostno « občutljivo ravna s svojimi fizično-prostorskimi pogoji za obstoj in kulturni razvoj ter $s$ tem gradi svojo mednarodno konkurenčnost.

»Interes države « glede uveljavljanja načel trajnostnega razvoja, kot jih opredeljujejo načrtovalni dokumenti, še ni dosegel izvedbene ravni. Problem izhaja iz enosmernosti procesov $\gg \mathrm{Z}$ vrha «, trajnostna usmeritev pa je mogoča le z uravnovešanjem procesov $\gg \mathrm{Z}$ vrha « in $\gg$ od spodaj navzgor «. Prvo vprašanje je torej, kako razviti koncept trajnosti kot izhodišče izobraževanja.

Za razvoj kulturne identitete posebno pozornost posvečamo $»$ kulturni« dimenziji trajnosti prostorskega razvoja. Pri tem je arhitektura pojmovana kot tisti bistveni del kulture, ki je prostorski pogoj in hkrati sled kulturnega delovanja (kulturno okolje - arhitekturni prostor). Evropska skupnost je že ugotovila, da je poleg fizičnega zdravja in korektnih odnosov med ljudmi, javni interes prav gotovo kakovostno bivalno okolje. Glede na opredelitev evropske direktive o poklicnih kvalifikacijah za področje arhitekture so »arhitekturno oblikovanje, kakovost zgradb, njihova usklajenost $\mathrm{z}$ okoljem, spoštovanje naravne in mestne krajine « zadeve »javnega interesa « vseh evropskih držav.

Vajemno priznavanje kvalifikacij mora zato temeljiti na merilih kakovosti in kolicine, ki zagotavljajo, da so osebe spriznanimi kvalifikacijami sposobne razumeti in uresniciti potrebe posameznikov, družbenih skupin in organov oblasti, kar zadeva prostorsko načrtovanje, oblikovanje, organizacijo in realizacijo struktur, obranitev in izkorišcanje stavbne dedisčine in zascito naravnega ravnovesja (internet 1).

Arhitektura kot generalistična stroka torej obravnava grajeno okolje v najširšem smislu, v odnosu do naravnega, kot kulturno okolje. Problem določitve pomembnih vsebin nakazuje potrebo po razlagi trajnostnega razvoja kot javnega interesa na primerih, v katerih je ta najbolj ogrožen in so takojšnje intervencije najnujnejše - eden ključnih je javni prostor. V Sloveniji še niso vzpostavljeni pogoji za konkretno zaščito tega. Številni primeri dogajanja v slovenskem prostoru kažejo, kako lahko neustrezno ravnanje enega človeka izniči pozitivna prizadevanja širše skupnosti. Kako torej opredmetiti pojem kulturne trajnosti prostorskega razvoja?

Projekt se ukvarja predvsem s problematiko splošnega izobraževanja. Tematski poudarek je namenjen osnovnošolskemu in splošnemu srednješolskemu izobraževanju. Dosedanje analize osnovno- in srednješolskih programov obravnavajo predvsem abstraktni, konceptni vidik trajnostnega razvoja (internet 2). Izkustveni pristop se sicer pojavlja, vendar je zanemarjen njegov bistveni pomen v splošnem izobraževanju. Izkustveni pristop, ki je najmlajši generaciji najbližje, ponuja namreč najvišjo stopnjo učinkovitosti posredovanja idej (Zupančič in Juvančič, 2003). Otroci in mladostniki spoznavajo svet najprej izkustveno in ga sproti konceptualizirajo. Iz tega izhaja potreba, da se tudi $s$ trajnostnimi načeli spoznajo izkustveno: od svoje sobe, prek domačega praga, do soseda, ulice, naselja ... Eden temeljnih problemov obravnavane tematike $\mathrm{z}$ znanstveno-razvojnega vidika je torej v pristopu. Najpomembnejše vprašanje pa: kako doseči preobrat $\mathrm{v}$ pristopu in komplementarnost obeh, $s$ prednostjo izkustvenega $\mathrm{v}$ zgodnejših fazah izobraževanja. $\mathrm{V}$ povezavi z vprašanjem o »opredmetenju « kulturne trajnosti bi lahko dodali: ali lahko pojem kulturne trajnosti opredmetimo tako, da obenem dosežemo potreben preobrat $\mathrm{v}$ pristopu $\mathrm{k}$ splošnemu izobraževanju o trajnostnem razvoju. Kaj moramo upoštevati pri izbiri in morebitnem uvajanju novih načinov posredovanja arhitekturnih vsebin otrokom in mladostnikom?

Namen projekta je torej prispevati k celovitemu sooblikovanju pogojev za učinkovitejše izobraževanje o učinkovitih, konkretnih prispevkih $\mathrm{k}$ trajnostni razvojni usmeritvi, $\mathrm{s}$ poudarkom na grajenem okolju oziroma arhitekturi.

V celotnem projektu se prepletata induktivni in deduktivni pristop. V nalogi se problematika obravnava interdisciplinarno skozi poglede pomembnih ved, ki se vključujejo (bi se morale vključevati) v izobraževalni proces o trajnostnem razvoju graje- 
nega okolja - $\mathrm{v}$ povezavi $\mathrm{z}$ arhitekturo, urbanističnim načrtovanjem, razvojno psihologijo, s pedagogiko itd. Prevladuje opisna metoda, dopolnjuje jo empirični pristop (vključno $s$ statistično obdelavo podatkov, $s$ prilagoditvijo trenutno uporabljene - pri preverjanju učencev v nadaljevanju raziskave).

V pričujočem prispevku so obravnavani ti cilji/rezultati: 1. opredeliti vlogo izobraževanja o grajenem okolju v konceptu trajnostnega razvoja;

2. pripraviti izhodišča za prilagajanje načinov posredovanja arhitekturnih vsebin;

3. opredeliti izobraževalne vsebine in njihove predstavitve glede na razvojne sposobnosti ciljne publike, in sicer za:

- preverjanje stopnje osveščenosti otrok oziroma mladostnikov o »trajnostnih arhitekturnih « temah ter tudi za

- ugotavljanje usposobljenosti vzgojiteljev in učiteljev za posredovanje znanja s področja grajenega okolja v povezavi s trajnostnim razvojem.

Prispevek predstavlja pregledni del omenjene raziskave: pregled vidikov, ki so nujni ob pripravi eksperimentalnega dela. Pomenski vidik (Zakaj je treba razviti koncept trajnostnega prostorskega razvoja kot izhodišče izobraževanja?) je dopolnjen z vsebinskim (Kaj konkretizirati, ko razmišljamo o kulturni dimenzijo trajnostnega prostorskega razvoja, še posebej o pojmu bivalne kulture?). Načinovni vidik (Kako konkretizirati obravnavane pojme?) pa je razvit predvsem z vidika teorije predstavitev (kot dela arhitekturne teorije). Glede na ciljno publiko sta obravnavana še razvojnopsihološki (otroci in mladostniki) ter didaktični vidik (učitelji).

Pregled končuje sintezna konkretizacija pojma kulturne trajnosti prostorskega razvoja: izbor in vizualizacija aktualnih konkretnih pojavov v prostoru za izbrano ciljno publiko v obliki anketnega vprašalnika. $V$ prispevku so prikazani vzorčni primeri te sinteze.

Naslovi poglavij tega prispevka izhajajo iz projektnih ciljev:

- Razvoj koncepta trajnostnega razvoja kot izhodišča izobraževanja (cilj 1),

- Opredmetenje pojma kulturne trajnosti prostorskega razvoja (cilj 1),

- Izbor možnosti konkretizacije (cilj 2),

- Vizualizacija bivalne kulture (cilja 2 in 3),

- Razumevanje abstraktnih pojmov pri otrocih (cilj 3),

- Vloga učitelja pri vzgoji in izobraževanju za trajnostni razvoj (cilj 3) ter

- Konkretizacija: anketa za otroke in mladostnike (cilj 3).

Sklepno poglavje pa povzema ugotovitve in nakazuje nadaljnje delo.

\section{Razvoj koncepta trajnostnega razvoja kot izhodišča izobraževanja}

Prihodnost človeštva in kakovost življenja je odvisna od človekove zmožnosti za doseganje trajnostnega ravnovesja z globalnim okoljem. Uravnoteževanje človekovih potreb po ohranjanju naravnega in grajenega okolja $\mathrm{v}$ sedanjosti in prihodnosti povezujemo torej s pojmom trajnostnega ravnovesja, razvoj pa s pojmom trajnostnega razvoja. Čeprav ideja tovrstnega razvoja ni povsem nova, so bila načela trajnostnega razvoja, sprejeta leta 1992 v Riu de Janeiru v Agendi 21 (internet 3), pomembno prelomnico $\mathrm{v}$ pojmovanju človekovega razvoja in hkrati izhodišče številnim strateškim dokumentom na svetovni, evropski in državni ravni. $V$ devetdesetih letih je trajnostni razvoj postal vodilo okoljske politike EU.

Vsebinsko gledano pojem » trajnostni razvoj « na splošno opredeljujemo kot razvoj, ki zadošča današnjim generacijam, ne da bi pri tem ogrožal razvoj prihodnjih generacij (internet 3). Plut (2007) opozarja, da trajnostni razvoj ni vsebinsko najboljši prevod za »sustainable development «. Slovar slovenskega knjižnega jezika razlaga pojem »trajnost « kot »značilnost česa glede na to, koliko časa lahko obstaja, je uporabno « (DZS, 2002). Po Plutu $(2005,2007)$ pojem $\gg$ trajnostnost « poudarja cilj, težnjo trajnega oziroma trajnostnega ohranjanja naravnega (okoljskega) kapitala in hkrati dolgoročno (trajno) zasnovanega gospodarstva in celotne družbe. Pojem je uporaben, če želimo poudariti širšo skrb za dvig široko pojmovane kakovosti življenja, enakost ljudi v sedanjosti in v prihodnosti, seveda $\mathrm{v}$ okviru zmogljivosti okolja, narave. Pojem »sonaraven « je po njegovem mnenju ožji in se veže na udejanjanje načel varstva okolja in narave, torej na okoljsko trajnostnost. Medtem ko pojem »trajnosten « označuje in poudarja časovno komponento, pojem »sonaraven« označuje način delovanja, gospodarjenja, ki je skladen $\mathrm{z}$ naravo.

V članku se sicer »omejujemo « na grajeno okolje, vendar v odnosu do naravnega, $s$ »pridihom « kulture. Okolje v najširšem smislu pojmujemo kot naravno okolje, antropogeno preoblikovano naravno okolje (obdelovalne površine, gojeni gozd, urejene vodne razmere) in pretežno antropogeno ali tehnogeno (naselja, predvsem mesta, industrijske in prometne naprave (Ilešič, 1979). Slednje v novejšem času označujemo kot »grajeno okolje «. Po Evrotermu (internet 4) je grajeno okolje (ang. built environment, nem. gebaute Umwelt) tisti del nežive narave, ki ga ustvari ali upravlja človek, na primer od stavb in drugih večjih objektov, cest, mostov, in podobno, do manjših objektov, na primer semaforjev, telefonskih govorilnic in stebričkov. $V$ članku povezujemo trajnostni razvoj v grajenem okolju z njegovo kulturno komponento oziroma z njegovo kakovostjo. Kakovost grajenega okolja namreč pomembno prispeva $\mathrm{k}$ uravnoteženemu trajnostnemu razvoju. 
Izobraževanje o trajnostnem razvoju v grajenem okolju je pomemben dejavnik za udejanjanje načel trajnostnega razvoja. Večina strateških dokumentov o trajnostnem razvoju poudarja proaktivno politiko izobraževanja ter usposabljanja otrok in mladine na področju trajnostnega razvoja (internet 5; internet 6). Agenda 21 (internet 3) poudarja, da okoljsko izobraževanje razvija vrednote, oblike ravnanja in odgovornosti, potrebne za sodelovanje pri ustvarjanju trajnostno uravnotežene prihodnosti. Tematska strategija za urbano okolje (internet 7) priporoča lokalnim organom spodbujanje uporabe metod trajnostne gradnje z ozaveščanjem prebivalstva. Menimo, da ima izobraževanje o grajenem okolju pomembno vlogo na področju trajnostnega razvoja le, če usposablja ljudi za soodločanje o problemih okolja in njegovega razvoja. Gre torej za vzgojo posameznika, ki bo zmožen kritične presoje človekovega vpliva na grajeno okolje ter se bo zavedal okoljskih prednosti, priložnosti in težav, hkrati pa bo imel znanje in sposobnosti za ustrezno delovanje pri skrbi za grajeno okolje. Posameznika, ki bo s svojim delovanjem omogočal trajnostni razvoj, reševal obstoječe probleme in preprečeval nastanek novih.

\section{Opredmetenje pojma kulturne trajnosti prostorskega razvoja}

Zakaj posredovati arhitekturno-urbanistične vsebine in etiko poseganja $\mathrm{v}$ prostor splošni javnosti ter zlasti mlajšim generacijam? Za doseganje kulturne trajnosti prostorskega razvoja so pomembna formalna pravila (zakoni, pravilniki, prostorski akti itd.) - ki omogočajo sodelovanje javnosti v načrtovalskih procesih, predpisujejo, omejujejo in sankcionirajo dejanja $\mathrm{v}$ prostoru -, hkrati pa aktivno izobraževanje vseh akterjev (tudi potencialnih) o arhitekturi in etiki delovanja v prostoru. Razširjanje procesa učenja in spoznavanja sveta na vsa življenjska obdobja posameznika sovpada z razširjenim pogledom stroke na relacijo prostor-uporabnik ter prostorsko problematiko, ob katero »zadeva « v različnih življenjskih okoliščinah in na različnih stopnjah (starostnih, zrelostnih, izobraževalnih, interesnih). Postopno in stopnjam prilagojeno izobraževanje o prostorskih vsebinah ima očitno prednost pred izobraževanjem v smislu spreminjanja že izoblikovanega sistema vrednot, stališč in prepričanj posameznih ciljnih skupin javnosti. Prednost zgodnjega in postopnega učenja se izkazuje tudi pri pravočasnem posredovanju tovrstnih vsebin oziroma še pred obdobjem posameznikovega aktivnejšega poseganja v prostor.

Pomen kulturne trajnosti si običajni uporabnik prostora težko predstavlja. Če večina splošne javnosti ob besedah »okoljski« oziroma »trajnostni« pomisli le na naravne vidike teh pojmov ter medsebojne odnose med človekom in naravo, ta miselni koncept izpušča prav tako bistveno - kulturno komponento. Še posebej v času, v katerem se meje med kulturno in naravno krajino nezadržno brišejo, tudi kulturne in naravne komponente trajnostnega razvoja ni več mogoče obravnavati ločeno. Podobnega mnenja so tudi nekateri avtorji, ki trdijo, da pri trajnostnem razvoju ne gre le za oprijemljive oziroma fizične pojme, temveč »trajnostno « vključuje tudi družbene, estetske in ekonomske vidike, $\mathrm{v}$ povezavi $\mathrm{z}$ dobrim počutjem posameznika in skupnosti. Kljub različnim definicijam in številnim vidikom celotnega spektra trajnostne problematike se večina piscev strinja, da oblikovanje bivalnega okolja (v najširšem pomenu besede), ki vključuje arhitekturo in urbanizem ter tudi druge vede, ki se ukvarjajo z načrtovanjem, gradnjo in poseganjem v prostor, pomembno vpliva na kakovost okolja oziroma kakovost bivanja $\mathrm{v}$ splošnem (pozitivno in negativno). Hagan (2001) meni, da je arhitektura vedno posedovala ambivalentno pozicijo med naravnim in kulturnim, ki se z zasledovanjem trajnostnega razvoja le še poglablja.

Kako lahko pojem prostorske trajnosti približamo uporabnikom in mlajšim generacijam, ki so vključeni v proces izobraževanja? Vso trajnostno problematiko na področju oblikovanja prostora zlahka strnemo okoli (za vsakega posameznika eksistencialno pomembnega) pojma bivanja - bivanje pa najpogosteje povezujemo z bivališči - arhitekturo, njihovim umeščanjem $\mathrm{v}$ prostor in njihovimi medsebojnimi razmerji urbanizem, prostorsko načrtovanje. Širši pomen bivanja zajema večino človekovih aktivnosti, ki se začnejo v bivališču in njegovi bližnji okolici, nadaljujejo pa z vprašanji transporta, komuniciranja, dela in delovnega okolja, vse do preživljanja prostega časa - večina od naštetih je vsaj posredno povezana $\mathrm{z}$ vprašanjem oblikovanja stavb in prostora. Takšna perspektiva preusmerja pogled $\gg$ zviška « - od globalnih razsežnosti, nepredstavljivega merila in kvantitete ter množičnosti - na optiko vsakega posameznika, njegovih izkušenj in vsakdanjih dejanj, ki jih ta lažje razume in obvlada.

Podajanje kulturne trajnosti prostorskega razvoja je tako na prvi stopnji smiselno konkretizirati na konceptu lokalnega: »Vsa trajnost je lokalna « (McDonough, 1998: 49). Posameznik namreč vedno izhaja in deluje najprej lokalno, v smislu, tu sem, táko naravno in kulturno okolje me obdaja ter v tákih družbenih, filozofskih in ekonomskih okvirih se gibljem. Že omenjeno osrediščenje pojma trajnosti okoli bivanja preusmerja optiko poseganja v prostor na posamezne akterje, v katerih se vsak posameznik zlahka prepozna, lažje predstavlja in vanje vživlja.

Pri podajanju okoljske problematike in problematike poseganja $\mathrm{v}$ prostor je treba kar se da enakovredno osvetliti vse tri stebre trajnostnega razvoja (naravni, družbeni in ekonomski) ter koherence med dejavniki, ki tvorijo prostor. Pri tem je pomembno izobraževati tudi o tistih procesih in pojavih, ki so teže merljivi in katerih posledice se v prostoru uresničujejo $s$ časovnim 
zamikom oziroma so manj prisotni v zavesti ljudi ali jih zaradi njihovih lokalnih posebnosti težje posplošimo. Ob spoštovanju naravnih danostih je tako treba upoštevati tudi spoštovanje kulturnih danosti: spoštovanje uporabnika in njegovih potreb (pomembnost dobrih zasnov), obstoječih kakovostnih tradicionalnih prostorskih sledi v prostoru, družbeno-ekonomskih razmer, vključenost vseh skupin in posameznikov v odločanje in sooblikovanje okolja ipd. ter ekonomske vzgibe za trajnostno delovanje (dolgoročni in kratkoročni prispevek).

Neposeganje in nematerializacija sta lahko v določenih primerih (naj)boljša »posega « $\mathrm{z}$ vidika trajnostnega razvoja, celo boljša od gradnje, spreminjanja in preoblikovanja. Premislek in razumna vzdržnost pri posegih zato veljata kot vrednoti prek vseh meril poseganja v prostor. Med osnovnimi vsebinskimi elementi, ki jih je v procesu splošnega izobraževanja smiselno predstaviti, so vsebine, povezane $\mathrm{z}$ gradnjo in $\mathrm{s}$ poseganjem $\mathrm{v}$ grajeno okolje.

\section{Izbor možnosti konkretizacije}

Poglavje o izhodiščih za prilagajanje načinov posredovanja arhitekturnih vsebin preusmerja dosedanji razmislek $\mathrm{k}$ vprašanju: Kdo kaj posreduje, komu, kako in zakaj tako?

Predvidevajmo najprej, da je »kdo《 arhitekt in je »kaj « arhitekturna vsebina, torej to, kar oblikuje kakovostno arhitekturo kot enega bistvenih pogojev kulturnega preživetja družbe, ki to arhitekturo soustvarja. Vzemimo za primer poskus posredovanja pojma kakovosti arhitekture. Arhitekti se, samoumevno, zatečemo $\mathrm{k}$ vidnemu sporočanju. Pojem lahko ponazorimo $s$ simbolom, s katerim izzivamo domišlijo »bralca « in njegove konkretne asociacije, ali pa s primerom, pri čemer ga bolj »prikujemo « v konkretno predstavo o nečem, s čimer se morda sploh ne strinja. Lahko izberemo primer arhitekture, o katerega kakovosti se npr. strinja določena $\gg$ srenja «, in to morda celo v daljšem časovnem obdobju. Lahko pa poudarimo primer ljudi, ki se v določenem prostoru dobro počutijo, in jih pokažemo $\mathrm{v}$ tem prostoru. In vendar je pojem kakovosti arhitekture »konkretnejši «, vsaj »ožji pa sta manj kompleksna kot npr. pojem »razvoja « nasploh. Po drugi strani pa bi verjetno pojem razvoja, kakršnega-koli-že, lažje vizualizirali kot pojem trajnostnega razvoja. Pojem arhitekture nasploh verjetno mnogo lažje kot pojem kakovostne arhitekture. Ali res? Arhitektura » nasploh « je lahko dejavnost ali pa sled dejavnosti - pri pojmu »kakovostne arhitekture « pa se vsaj na prvi »pogled « zdi, da gre za arhitekturni prostor. Pomembni izhodišči za prilagajanje načinov sporočanja so torej abstraktnost, kompleksnost in predstavljivost sporočila.

Vsebine sporočil, ki jih želimo posredovati, se razlikujejo najprej glede na to, kako sami razumemo obravnavano pro- blematiko in kako jo razume naša ciljna publika. $V$ danem primeru je na »eni strani « interdisciplinarna projektna skupina, na »drugi strani « pa so otroci in mladostniki ter njihovi učitelji. Gre za razlike glede »trajnostne osveščenosti « ciljne publike ter med posredovalcem in izbrano ciljno publiko. Te razlike so pogojene razvojno, izobrazbeno ..., kažejo se v vrednostnih sistemih, vplivajo na cilje pri sooblikovanju prostora ... Vprašanje pa je, kako so različni akterji v komunikacijskem procesu sposobni vidno posredovati svoje miselne predstave o prostoru, da bi najprej ugotovili, potem pa tudi »presegli « razlike glede vrednostnih sistemov in ciljev v medsebojnem dialogu. Pri tem igra pomembno vlogo tudi - spet razvojno, izobrazbeno ... pogojen - način mišljenja (sposobnost abstraktnega mišljenja). Način sporočanja se mora torej odzvati na: »trajnostno « osveščenost, abstraktnost mišljenja in vidno usposobljenost ciljne publike.

Kakšne pa so sploh možnosti glede načina sporočanja? Pristop je odvisen od »pogleda na svet « (Bosselman, 1997: 2-19), ki je lahko, podobno kot samo sporočilo, abstrakten ali konkreten. Konkreten izhaja iz izkustva neposredno, abstrakten posredno. Primeri prvega so na primer. perspektivna risba, fotografija $\mathrm{z}$ realistično oddaljenostjo in kotom objektiva, digitalno okolje, ki je odvisno od spremembe opazovalǐ̌ča, v njem je na primer človek konkretno merilo. Primeri drugega načina pa so aerofoto posnetki, karte mesta, načrti ..., ki jim lahko abstraktno določimo tudi merilo. Načeloma izbor enega izmed navedenih pristopov, njune polarne kombinacije ali pa vmesnih možnosti ni odvisen od izbora medija predstavitve. Ob konkretnem delu pa pridemo do ugotovitve, da so za posamezna sporočila pač nekateri mediji boljši od drugih: učinkovitejši, realnejši ... (Juvančič in Zupančič, 2008). Pomembna sta, skratka: abstraktnost in medij predstavitve.

V naslednjem poglavju je »kaj《 bivalna kultura, »kako« pa vizualizacija, ki se glede na to, »komu « vizualiziramo, ne podreja nujno prevladi likovno-estetskih kriterijev, čeprav je tisti $\gg k d o \ll$, ki vizualizira, arhitekt. Izbor kombinacij elementov lahko ponazarja odnos do bivalne kulture, tudi če likovnost zavestno zanemarimo.

\section{Vizualizacija bivalne kulture}

Ena od prvin trajnosti razvoja posameznika ali skupine ljudi je kultura bivanja. Pojem kultura je »delna rezultanta sil « dosežkov oziroma vrednot človeške družbe ter posameznikovega delovanja in ustvarjanja. Če temu dodamo še pojme, kot so prebivati, stanovati, živeti eksistirati, biti, obstajati, je v končnem rezultatu zaobseženo pravzaprav vse, kar človek počne v svojem življenju. To pomeni, da se stopnja kulture posameznika ali skupine ljudi najneposredneje kaže prav v najintimnejšem načinu bivanja, stranski proizvodi tega bivanja 
pa so njegove vidne posledice. Urejenost zasebnega bivalnega ambienta je pri nižji stopnji kulture bivanja človeka pogosto v nasprotju z njegovim odnosom do poljavnega ali javnega bivalnega ambienta. Začenši z odnosom do skupnih dobrin - zelenih površin, mirujočega prometa, odpadkov. Temeljno zgodovinsko izhodišče kulture bivanja je gotovo v geografski lokaciji, ki je bila vedno tesno povezana s podnebnimi vplivi. Kultura bivanja v severnih geografskih širinah se je in se še danes nedvomno razlikuje od kulture bivanja na primer $\mathrm{v}$ Sredozemlju. $Z$ razvojem tehnologije in komunikacij vseh vrst ter tako imenovane globalizacije so se različne bivalne kulture po svojih značilnostih že močno približale druga drugi. Danes razlike v bivalni kulturi bolj narekuje stopnja gospodarskega in političnega razvoja nekega območja, kar je mogoče zaznati tudi v vse bolj celostnem in univerzalnem likovnem izrazu arhitekture, ki vse bolj zaposluje naš percepcijski aparat. Človek namreč zazna od vseh okoljskih dražljajev približno tri četrtine vseh informacij prek svoje vidne zaznave. Pri tem zazna opazovalec pri ustrezni osvetljenosti, strukturo, teksturo in barvo, ki so v medsebojni odvisnosti. Le-ta je pogojena z razmerjem opazovalec - opazovani objekt oziroma z oddaljenostjo opazovalca od objekta. Prostor zaznamo po razporeditvi objektov. Razvrstitev pa zaznamo prek razdalje. Razdalje vsebujejo smer in protismer. Torej je z nekega mesta vseeno, v kateri smeri opazujemo razvrstitev objektov (Bonča, 1990). Vidna predstavitev ali upodobitev posameznih prostorskih elementov ali sklopov zato pomeni pri ugotavljanju ravni bivalne kulture glavni način prenosa informacije o prostoru, hkrati pa omogoča vpogled v sposobnost človekovega dojemanja in razumevanje prostora, ki ga obdaja. Starost (izkušnja) ima pri tem zelo pomembno vlogo. Pravila likovnega izraza v kompoziciji elementov, oblik in barv, ki veljajo sicer $\mathrm{v}$ različnih predstavitvenih tehnikah, so $\mathrm{v}$ primeru nadgrajena $\mathrm{v}$ obliki likovnih poudarkov posameznih elementov in sklopov. Z odebeljeno črto - obrisom, $s$ kontrastno barvo, pretirano velikostjo in številom elementov, z abstrakcijo, namerno poudarjenimi napakami, s popačeno perspektivno geometrijo prostora ipd. Pri tem je upoštevana narava posameznega vprašanja ali sklopa vprašanj, na katerega se raziskava v anketnem delu osredotoča. Velikost, oblika in število elementov na hiši in zemljišču so na primer hipotetični in služijo le kot nabor možnosti, ki so na izbiro pri izpolnjevanju anketnega vprašalnika (slika 1 ).

\section{Razumevanje abstraktnih pojmov pri otrocih}

Razvojnopsihološke študije konsistentno kažejo, da otroci stvari in dogodkov okrog sebe ne razumejo na enak način kot odrasli: razumevanje dogodkov je povezano z motivacijo, s pozornostjo, predznanjem, sposobnostmi, stališči, z osebnostnimi lastnostmi, okoliščinskimi in s kontekstualnimi dejavniki, z vrednostnim sistemom in razvojnimi stopnjami (Gray, 1999; Haberlandt, 1994; Siegler, Deloache in Eisenberg, 2003). Na tem mestu seveda ne moremo podati ustreznega vpogleda v vse te dejavnike, zato bomo samo navedli nekatere najpomembnejše vidike razvoja mišljenja, ki so bistveni za vpogled $\mathrm{v}$ razumevanje konceptov prostora in trajnostnega razvoja pri otrocih, še posebej procesov internalizacije in formalizacije mišljenja ter razvoja konkretnih in abstraktnih oblik sklepanja.

Po eni strani koncept trajnostnega razvoja na miselni ravni vključuje različne elemente, med katerimi lahko izpostavimo okoljske, prostorske, estetske, zgodovinske, geografske, socialne, kulturne, logične in kontekstualne; posameznikovo razumevanje koncepta le iz enega ali omejenega števila teh elementov pomeni normativno razvojnopsihološko variacijo in je nujno povezano s specifičnim razumevanjem konceptov, ki so posredno ali neposredno povezani s pojmom trajnostnega razvoja. Po drugi strani pa podatki razvojnopsiholoških študij iz zadnjih desetletij konsistentno kažejo, da se različne oblike formalnologičnega mišljenja, ki so potrebne za vpogled v medsebojne odnose med likovnimi, prostorskimi in kontekstualnimi elementi konceptov, razvijajo šele med enajstim in dvajsetim letom starosti (Rice, 1998; Zupančič in Svetina, 2004) - torej v obdobju mladostništva. Razvoj formalnologičnega mišljenja je povezan z razvojem abstraktnega sklepanja in simbolnega mišljenja drugega reda. Prvi je povezan z razvojem operacij med pojmi in odnosi, ki so na konkretni ravni lahko samo hipotetični in nepredstavljivi, drugi pa z razvojem sposobnosti

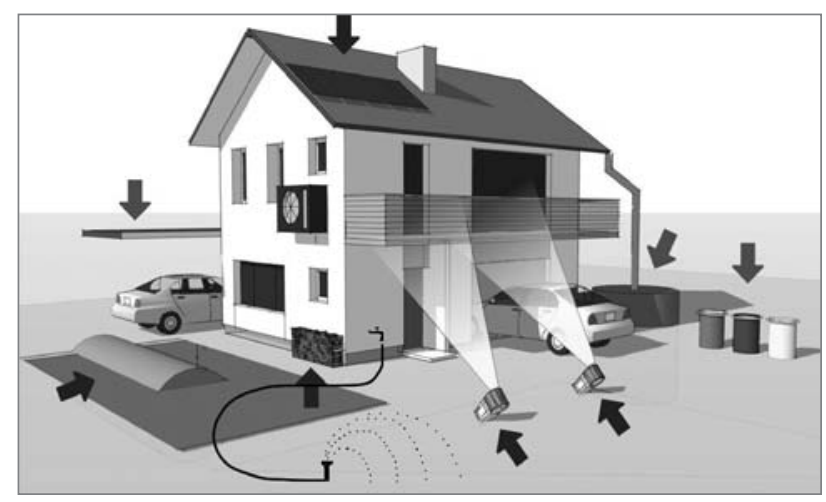

Slika 1: Navodilo učencu/dijaku: »|zberi okolju prijazne elemente in sisteme.« Prilagoditev za prvi osnovnošolski triadi: »Na sliki obkroži vse, kar pomaga ohraniti naravo.« (llustracije: Tomaž Novljan).

logičnih operacij med koncepti in predstavami na različnih ravneh abstraktnosti, oblikovanjem klasifikacij razredov, razumevanjem odnosov med odnosi ter razvojem metakognicije. Razvoj teh sposobnosti posamezniku omogoča, da lahko na miselni ravni presega omejitve konkretne, fizične stvarnosti, omogoča pa mu tudi metakontekstualno mišljenje in sklepanje brez konkretnih fizičnih predstav. Posameznik postane sposoben kompleksnejših oblik metakognicije in razvije vpogled $\mathrm{v}$ kompleksnost metafor, simbolov in odnosov med elementi 
miselnih konceptov, ki so nujni za kompleksno razumevanje pojma trajnostnega razvoja.

Da bi lahko otrokom in mladostnikom predstavili vsebine pojma trajnostnega razvoja, moramo te vsebine konkretizirati in jih umestiti v okolje otrokovih izkušenj, pri tem pa moramo seveda upoštevati tudi posebnosti konteksta in posameznikovega razvojnega obdobja, tako na miselni kot na motivacijski in socialni ravni.

\section{Vloga učitelja pri vzgoji in izobraževanju za trajnostni razvoj}

Pri vzgoji in izobraževanju za trajnostni razvoj v grajenem okolju gre za izrazito prepletanje spoznavne, čustvene, estetske in vedenjske sestavine. Učenje pojmov, zakonitosti in teorij se prepleta $\mathrm{z}$ učenjem stališč in vrednot. Posebna pozornost je namenjena otrokovemu in mladostnikovemu doživljanju estetsko spodbudnih trajnostno naravnanih objektov in materialov ter razvijanju odnosa do grajenega okolja, ki se vzpostavlja v konceptu trajnostnega razvoja. V družbeno-kulturnem okolju $s$ tehnološkim razvojem in razvojem informacijsko komunikacijskih tehnologij otrok in mladostnik prehaja med šolskim in domačim okoljem ter drugimi virtualnimi in fizičnimi okolji. Otrokovo in mladostnikovo doživljanje in odnosi v teh okoljih, pristopi k učenju, povezanost formalnega in neformalnega učenja ter interesi sooblikujejo pripravljenost na učenje. Cilji izobraževanja za trajnostni razvoj so usmerjeni k ohranjanju identitete, kulture in okolja, zaznavanju in spoznavanju sveta ter zavedanju njegovega trajnostnega razvoja (Salite, 2002). Pomembno je, da se posameznik zaveda svoje uspešnosti v teh okoljih. Otrokova in mladostnikova pričakovanja, zaznavanje sebe in svoje uspešnosti ter cilji, ki si jih zastavlja, nastanejo $\mathrm{v}$ interakciji z okoljem in prav tako vplivajo na okolje. Vzgoja temeljnih vrednot, med katere sodijo vrednote, ki zadevajo odnos in ravnanje $\mathrm{v}$ grajenem okolju, občutljivost za estetskost in kulturo bivanja, se prične v zgodnjem obdobju. Posameznik, ki se zgodaj sooči s problemi ravnanja z okoljem, spozna in ponotranji vrednote skrbi za okolje, bo z veliko večjo verjetnostjo ustrezno ravnal v odraslosti, ko bo v svojem profesionalnem življenju in v svojem družinskem okolju sooblikoval grajeno okolje.

Na področju vzgoje in izobraževanja za trajnostni razvoj velja izpostaviti zlasti nekatere didaktične vidike. Ali kurikularni pristopi pri vzpostavljanju vednosti o grajenem okolju podpirajo čutno, miselno in refleksivno zaznavanje in uporabo strategij vizualizacije, strategij abstrakcije, imaginacije, akcije in interakcije? So vsebine integrirane na vsa predmetna področja z ustrezno stopnjo medpredmetne povezanosti, ki zagotavlja nastavke za ustvarjalen razvoj trajnostne orientacije na vseh disciplinarnih področjih? Se spodbuja in zagotavlja medpred- metno snovanje vzgojno-izobraževalnih ciljev in vsebin? Je pri vključevanju vsebin v kurikul ustrezno upoštevano načelo avtentičnosti učnih vsebin in učnih metod za spodbujanje problemskosti, izkustvenosti in doživljajskosti pouka? Da vzgoja in izobraževanje za trajnostni razvoj doseže cilje na spoznavnih in vrednostnih ravneh ter vpliva na življenjski stil posamezni$\mathrm{ka}$, je potrebna interdisciplinarna narava obravnave trajnosti že pri prvem seznanjanju s tematiko pri zgodnjem učenju in prepletanje socialno-kulturnih vidikov, naravoslovja, tehnike in tehnologije ter okoljskega zdravja.

Med pomembne učiteljeve kompetence sodi usposobljenost za razvijanje odnosa, vrednot, znanja in izkušenj, potrebnih za varovanje in izboljševanje kakovosti življenja v grajenem okolju ter njegovega trajnostnega razvoja. Med učiteljevimi generičnimi in predmetno-specifičnimi kompetencami naj bi bilo poglobljeno znanje o grajenem okolju kot pomembnem sestavnem delu človekovega okolja ter o človekovi aktivnosti $\mathrm{v}$ grajenem okolju in kulturi bivanja za zagotavljanje kakovostnega življenja in trajnostnega razvoja.

\section{Konkretizacija: anketa za otroke in mladostnike}

Ob prepoznavanju vedenja o trajnostni problematiki v grajenem okolju smo v predhodnih poglavjih omenjena načela sintetizirali in opredmetili v obliki konkretnih ilustriranih vprašanj. Tako smo prihodnje akterje v prostoru povprašali, kako bi se odločali v življenjskih okoliščinah, povezanih z gradnjo in zato tudi $s$ trajnostnim razvojem prostora. Vprašanja smo pripravili v skladu s tematskimi sklopi, ki smo jih predhodno opredelili v pregledni matriki, $\mathrm{v}$ kateri smo navedli tudi ozadje posameznega tematskega sklopa, njegovo pomembnost za trajnostni razvoj ter vsebinsko obrazložitev in pomen posameznega vprašanja. Izdelali smo primerljivi različici vprašalnika in $s$ tem zaobjeli 3 starostno/razvojne stopnje: prvo, od 1. do 3. razreda osnovne šole; drugo, od 4. do 6. razreda, in tretjo, od 7. razreda osnovne šole do 4. letnika gimnazije. Različice izhajajo iz enake grafične osnove, vendar je ponekod prilagojena struktura modela naloge (povezovanje namesto nizanja, barvanje namesto obkrožanja itd.), prilagojeno je tudi izrazje $\mathrm{v}$ besedilu nalog, tip pisave (velike in male tiskane črke). Prvo in drugo stopnjo loči predvsem opisno vprašanje »Zakaj? «, ki preverja vzgibe in razloge za izbiro posameznega odgovora (pri prvi stopnji odgovora nanj nismo pričakovali). Vsa vprašanja so ilustrirana in $\mathrm{v}$ glavnem zaprtega tipa; odprti so odgovori na že omenjeno vprašanje »zakaj « in tista vprašanja, ki predvidevajo odgovore v obliki grafičnega izražanja s krajšimi opisi. Vprašalnik obsega 6 pokončnih A4-strani (20 vprašanj).

Med pripravo prispevka izvajamo anketiranje na izbranih šolah: 3 osnovne šole in 3 gimnazije (celotne populacije teh šol, 
približno 3500 enot). Ker raziskava med nastajanjem tega prispevka še poteka, o vrednotenju rezultatov ankete zaenkrat ne moremo poročati. $V$ tem trenutku je rezultat projekta anketa in proces njene priprave.

Ilustrirana vprašanja se ukvarjajo z bivališči (slika 2) in drugimi objekti (slika 3), njihovim umeščanjem v okolje, njihovim oblikovanjem, velikostjo ter odnosom anketirancev do grajene kulturne dedišcine in prostih površin. Vprašani so lahko izbirali tudi med različnimi načini materializacije (od različnih zazidav, zazelenitve do ohranjanja nepozidanih površin). Ugotavljamo tudi njihov odnos do različnih vsakdanjih dejavnosti (promet, nakupovanje, prosti čas), ki sooblikujejo naš bivanjski prostor (slika 4). Pri zadnjem vprašanju smo želeli preveriti odnos vprašanih do lokalnega okolja, ki ga poznajo - za skupni imenovalec vseh vprašanih $\mathrm{z}$ ene ustanove smo izbrali šolski vhod. Zanj so učenci/dijaki z risarskimi in besedilnimi odgovori ugotavljali, kaj mu manjka, kako bi ga spremenili ali
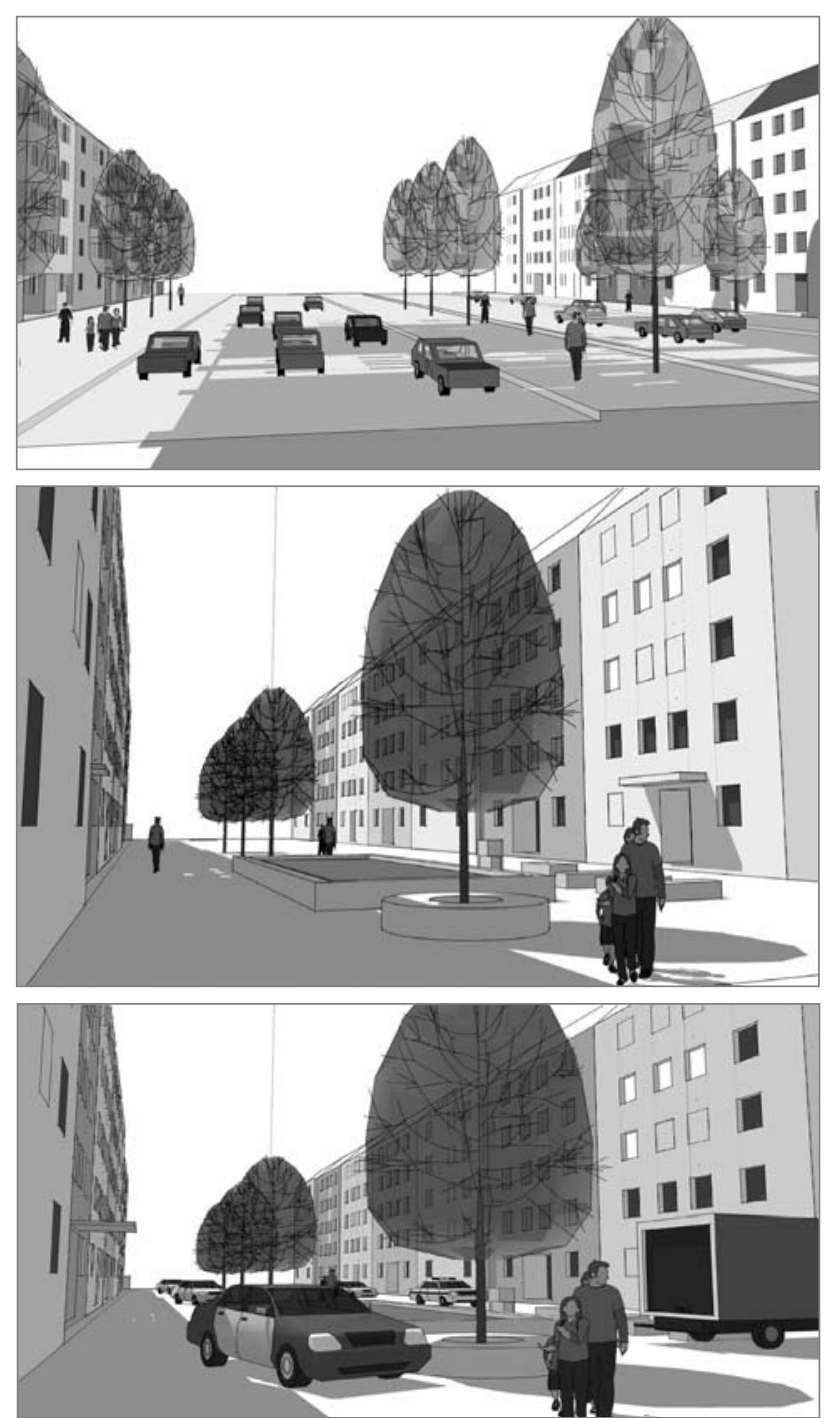

Slika 2: Vprašanji učencu/dijaku: »V kateri ulici bi raje živel? Zakaj?« (llustracije: Tomaž Novljan).
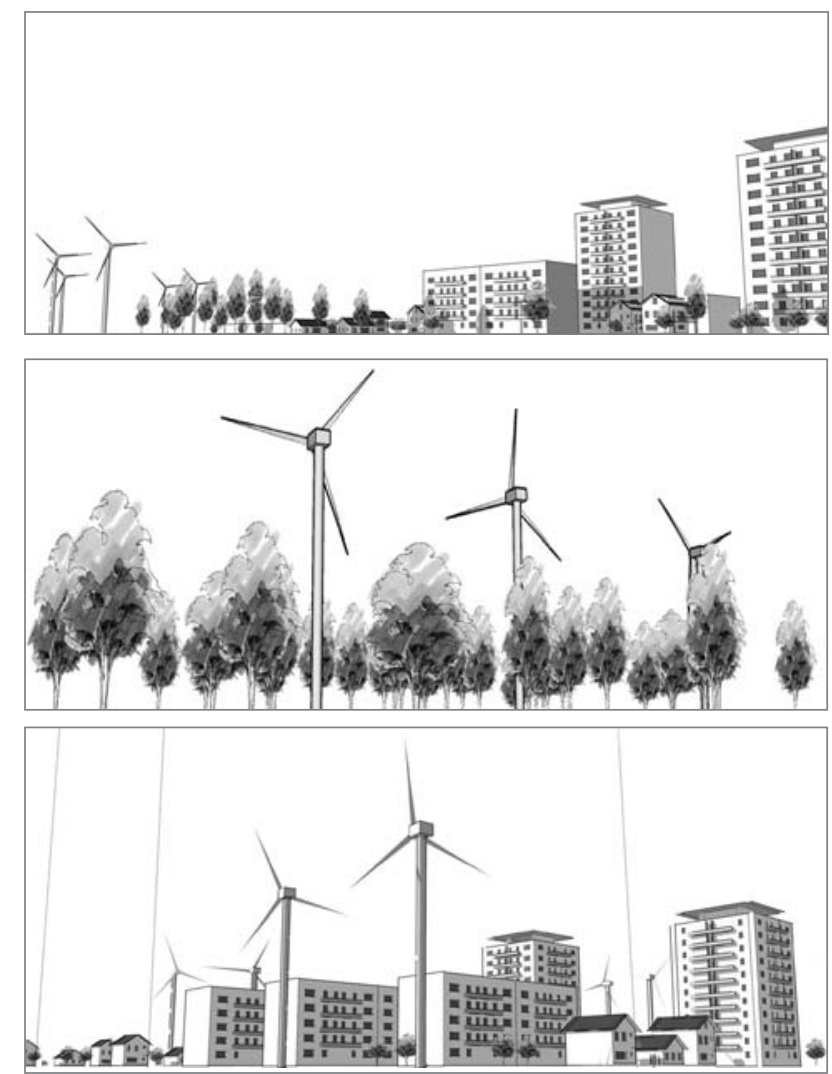

Slika 3: Vprašanji učencu/dijaku: »Katero okolje se ti zdi najprimernejše za vetrnice, ki proizvajajo električno energijo? Zakaj?« Za prvi osnovnošolski triadi je vprašanje prilagojeno s spremembo: električna energija - elektrika (ilustracije: Tomaž Novljan).

dopolnili. Na ta način smo dobili, poleg dveh različic vprašanj za različne stopnje, še šest različic vprašalnikov glede na šolo $(2 \times 6=12$ različic vprašalnikov). Zaradi omejenega prostora predstavljamo le izbor vprašanj.

Obravnavana anketa je predvidena tudi za komentarje učiteljev, saj so zanje dodana posebna vprašanja. Raziskava med slovenskimi učitelji obravnava učiteljeva pričakovanja, pripravljenost in prakso. Usmerjena je na analizo pojmovanj znanja, poučevanja in učenja na obravnavanem področju. Posebna skrb je namenjena analizi interakcije učitelja s kurikulum, $\mathrm{v}$ šolskem in lokalnem okolju ter njegovi interpretaciji vsebin in metodične zasnove, ki se izraža pri vzpostavljanju učnega okolja. Pregled metod in strategij poučevanja in učenja, ki so se uveljavile pri pouku za trajnostni razvoj s posebnim upoštevanjem grajenega okolja in kulture bivanja je obravnavan z vidika učiteljeve priprave in izvedbe. Procesno produktni model poučevanja (Brophy in Good, 1986) vključuje dejavnike poučevanja ne pa priprave na pouk. Analiza učiteljevih pristopov $\mathrm{k}$ poučevanju za trajnostni razvoj bo vključevala tudi učiteljevo pripravo za obravnavo »trajnostnih « tem. Če je učiteljevo ravnanje v razredu izvedeno na podlagi odločitev o metodah poučevanja in izboru učenčevih aktivnosti, ki so bile sprejete že v fazi priprave (Berliner, 1988; Bromme, 1992), je bil večji 

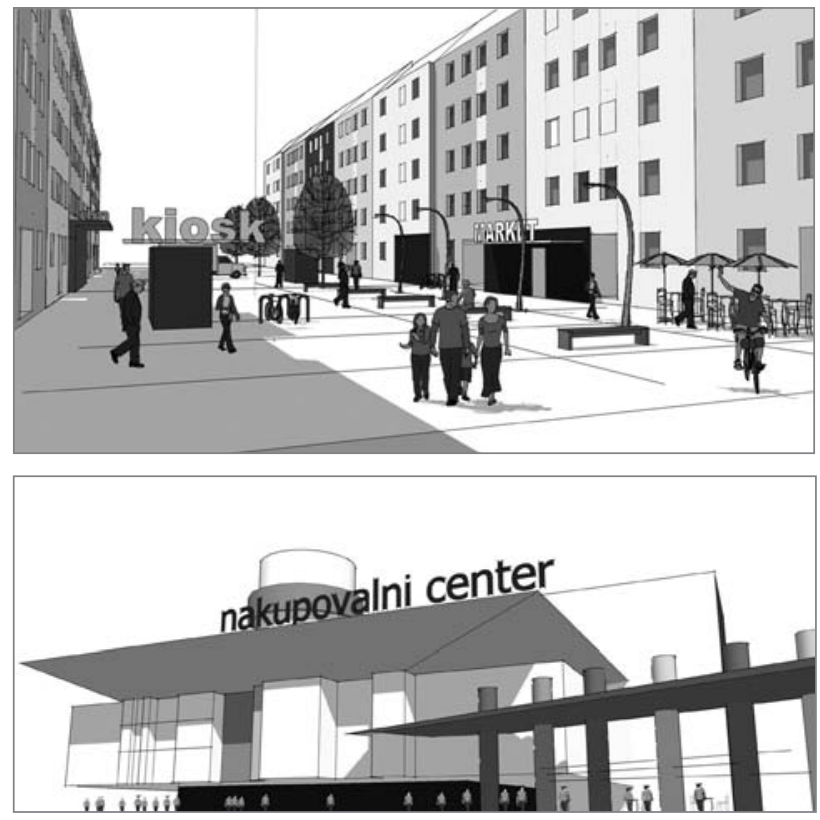

Slika 4: Vprašanji učencu/dijaku: »Kam bi šel raje nakupovat? Zakaj?« Za prvi osnovnošolski triadi je vprašanje prilagojeno z dodatkom: »s starši« (ilustracije: Tomaž Novljan).

del teh odločitev sprejet že med pripravo in ne pri izvedbi pouka. Učiteljevo odločanje je vezano na cilje, učne vsebine, učne metode in izobraževalno tehnologijo ter vire (Schulz, 1965). Analizi stanja na področju poučevanja in učenja za trajnostni razvoj bo vključevala pripravo in izvedbo, dejavnike, ki vplivajo na pripravo in evalvacijo izvedbe $\mathrm{v}$ odnosu na pripravo ter kakovost procesa in produktov.

\section{Sklep}

Trajnostni razvoj je dinamična kategorija. Zato je vedno znova treba razmišljati o kritični konkretizaciji izobraževanja o grajenem okolju. To izobraževanje ima lahko pomembno vlogo v trajnostnem usmerjanju prostorskih razvojnih procesov takrat, ko ljudi usposablja za dolgoročno odgovorno soodločanje o konkretnih problemih okolja in njegovega razvoja.

Kakovost prostora je v javnem interesu vsake države, torej kot nacionalni interes. Iz te kakovosti izhaja namreč tudi njena konkurenčnost. Več evropskih držav svojo konkurenčnost že »gradi«na tem spoznanju. Skromne razsežnosti kulturnoprostorsko občutljive dežele z bogastvom možnosti zahtevajo najvišjo raven osveščenosti o načelih trajnostnega razvoja in o možnostih za konkretne prispevke $\mathrm{k}$ izbrani razvojni orientaciji. Pomen vloge arhitekturnega izobraževanja v kontekstu doseganja » kulturne trajnosti « razvoja je torej več kot očiten.

Z deklarativnimi zapisi o trajnostnih načelih je vprašanje pomembnih vsebin rešeno le navidezno. Le $\mathrm{z}$ določitvijo načina posredovanja se vsebine ustrezno konkretizirajo in učinkovito posredujejo, prilagojeno sposobnostim ciljne publike na različnih ravneh formalnih in tudi neformalnih oblik izobraževanja.

Pri izbiri in morebitnem uvajanju novih načinov posredovanja arhitekturnih vsebin moramo upoštevati značilnosti vsebine sporočila: njegovo abstraktnost, kompleksnost in predstavljivost. Nič manj pomembne niso razlike med - razvojno, izobrazbeno ... pogojenimi lastnostmi posrednika in prejemnika informacij: stopnja osveščenosti glede izbrane tematike, sposobnost abstraktnega mišljenja in vidna usposobljenost (sposobnost vidne komunikacije). Ne nazadnje sta pomembna še stopnja abstraktnosti in medij predstavitve.

Da bi otrokom in mladostnikom lahko predstavili vsebine pojma trajnostnega razvoja, moramo te vsebine konkretizirati in jih umestiti v okolje otrokovih izkušenj. Pri tem pa moramo seveda zavestno upoštevati tudi posebnosti konteksta in posameznikovega razvojnega obdobja: na miselni, motivacijski in socialni ravni.

V večini arhitekturnih sporočil je likovnost bistvena nosilka sporočila o odnosu do bivalne kulture. Še posebej pri manjših otrocih. Za nadaljnje delo pa domnevamo, da lahko izbor kombinacij elementov, ki jih otroci sami še niso sposobni povezati v sistem, izraža odnos do bivalne kulture z vidika arhitekture, tudi če likovnost zavestno postavimo na drugo mesto - vsaj pri vizualizacijah, ki ne želijo konkretizirati pojma kulturne trajnosti razvoja samo prek konkretizacije pojma »lepega «, hkrati pa tudi ne izgubiti pridiha »kulture«.

Rezultati raziskovanja so - ob konkretnem nadaljnjem raziskovalnem delu - neposredno uporabni:

- pri ocenjevanju stopnje osveščenosti otrok oziroma mladostnikov o »trajnostnih arhitekturnih « temah v Sloveniji ter

- za ugotavljanje usposobljenosti vzgojiteljev in učiteljev za posredovanje znanja s področja grajenega okolja v povezavi s trajnostnim razvojem.

Razmislek o tem, kaj je treba upoštevati pri izboru in razvoju možnosti načina posredovanja arhitekturnih vsebin otrokom oziroma mladostnikom, bo razvit v klasifikacijo stopenj za vsako izhodišče posebej (stopnje abstraktnosti sporočila, stopnje osveščenosti ...), ta klasifikacija pa bo $s$ pomočjo razmisleka o pomenu kulture bivanja povezana v enovit sistem, ki bo v pomoč pri odločanju ob konkretnih preizkusih ter pri obravnavi konkretnih rezultatov v pričujočem in prihodnjih projektih.

Posredno so rezultati uporabni tudi za oceno vključenosti vsebin o grajenem okolju oziroma arhitekturi v izobraževalnih programih $-s$ poudarkom na slovenskem kulturnem prostoru - ali v celovitem postopku prenove izobraževalnih programov 
osnovnih in srednjih šol. Ne nazadnje pa prizadevanja vodijo še naprej: $k$ novim temeljnim in drugim razvojnim raziskavam, $\mathrm{k}$ odgovornemu strokovnemu delu, predvsem pa $\mathrm{k}$ procesu razvoja sistema vseživljenjskega učenja o arhitekturi.

Dr. Tadeja Zupančič, univ. dipl. inž. arh., docentka Univerza v Ljubljani, Fakulteta za arhitekturo, Ljubljana, Slovenija E-pošta: tadeja.zupancic@fa.uni-lj.si

Dr. Tomaž Novljan, univ. dipl. inž. arh., docent Univerza v Ljubljani, Fakulteta za arhitekturo, Ljubljana, Slovenija E-pošta: tomaz.novljan@fa.uni-lj.si

Dr. Matevž Juvančič, univ. dipl. inž. arh., asistent z doktoratom Univerza v Ljubljani, Fakulteta za arhitekturo, Ljubljana, Slovenija E-pošta: matevz.juvancic@fa.uni-lj.si

Špela Verovšek, univ. dipl. geogr., asistentka

Univerza v Ljubljani, Fakulteta za arhitekturo, Ljubljana, Slovenija

E-pošta: spela.verovsek@fa.uni-lj.si

Dr. Maruška Šubic Kovač, univ. dipl. inž. grad., izredna profesorica Univerza v Ljubljani, Fakulteta za gradbeništvo in geodezijo, Ljubljana, Slovenija

E-pošta: msubic@fgg.uni-lj.si

Dr. Andreja Istenič Starčič, univ. dipl. ped., docentka

Univerza v Ljubljani, Fakulteta za gradbeništvo in geodezijo, Ljubljana, Slovenija

E-pošta: andreja.starcic@siol.net

Dr. Matija Svetina, univ. dipl. psih., izredni profesor Univerza v Ljubljani, Filozofska fakulteta, Oddelek za psihologijo, Ljubljana, Slovenija

E-pošta: m.svetina@ff.uni-lj.si

\section{Viri in literatura}

Bonča, J. (1990): Okolje in zaznava okolja med gibanjem. Magistrska naloga. Ljubljana, Univerza v Ljubljani, Fakulteta za arhitekturo.

Bosselman, P. (1997): Representation of places - reality and realism in city design. Los Angeles, University of California Press.

Brophy, J., in Good, T. (1986): Teacher behavior and student achievement. V: Wittrock, M. C. (ur.): Handbook of research on teaching. New York, McMillan.

Bromme, R. (1992): Der Lehrer als Experte. Bern, Hans Huber Verlag.

Berliner, D. C. (1988): In pursuit of the expert pedagogue. Educational Researcher, 17, str. 5-13.

DZS (2002): Slovar slovenskega knjižnega jezika. Ljubljana.

Gray, P. (1999): Psychology. New York, Worth Publishers.

Haberlandt, K. (1994): Cognitive psychology. Boston, Allyn and Bacon.

Hagan, S. (2001): Taking shape: A new contract between architecture and nature. Oxford, Architectural Press.

Ilešič, S. (1979): Pogledi na geografijo. Ljubljana, Partizanska knjiga.
Internet 1: http://europa.eu.int/eurlex/lex/LexUriServ/site/sl/ oj/2005/l_255/I_25520050930sl00220142.pdf (sneto 1. 3. 2009).

Internet 2: http://www.rave-space.org/ravespace/homepage.aspx (sneto 10. 2. 2009)

Internet 3: http://www.un-documents.net/agenda21.htm (sneto 1. 3. 2009)

Internet 4: http://evroterm.gov.si/ (sneto 2. 3. 2009).

Internet 5: http://www.mop.gov.si/fileadmin/mop.gov.si/pageuploads/zakonodaja/konvencije/teritorialna_agenda_eu.pdf (sneto 1. 3. 2009).

Internet 6: http://www.mop.gov.si/fileadmin/mop.gov.si/pageuploads/zakonodaja/konvencije/leipziska_listina.pdf (sneto 1. 3. 2009).

Internet 7: http://eurlex.europa.eu/LexUriServ/LexUriServ.do?uri=C OM:2005:0718:FIN:SL:HTML (sneto 1. 3. 2009).

Juvančič, M., in Zupančič, T. (2008): Towards effective interfaces for general architectural learning: eco-spatial aducational interface for pupils. Arhitektura i sovremennye informacionnye tehnologii, 4(5), str. $1-8$.

McDonough, W. (1998): Declaration of interdependence. V: Scott, A. (ur.): Dimensions of sustainability: Architecture, form, technology, environment, culture, str. 45-55. London, New York, E\&FN Spon, an imprint of Routledge.

Plut, D. (2002): Teoretični in terminološki vidiki koncepta trajnosti/ sonaravnosti. Geografski vestnik, 74(1), str. 73-86.

Plut, D. (2007): Sonaravni razvoj (napredek) in geografija. Dela, 28 , str. 287-304.

Rice, F. P. (1998): Human development. Upper Saddle River, Prentice Hall.

Salite, I. (2002): Teachers' views on the aim of education for sustainable development. Journal of teacher education \& training, 2 , str. 68-80.

Schulz, H. O. (1965): Unterricht - Analyse und Planung. Hannover, Schroedel.

Siegler, R., Deloache, J., in Eisenberg, N. (2003): How children develop. New York, Worth Publishers.

Zupančič, T., in Juvančič, M., (2003): Vizualni jezik predstavitve prostora - ovira ali stičišče? Povečevanje učinkovitosti posredovanja idej o prostoru med splošno in strokovno javnostjo [The visual language of spatial presentations - a barrier, or a crossroad? Enhancing the efficiency of communicating spatial ideas to expert and lay publics]. Urbani izziv, 14(2), str. 35-43 [100-104].

Zupančič, M., in Svetina, M. (2004): Spoznavni razvoj v mladostništvu. V: Marjanovič Umek, L., in Zupančič, M. (ur.): Razvojna psihologija, str. 525-545. Ljubljana, ZIFF. 